\title{
Exploitation of Oil Fields and Sustainable Development of the Environment
}

\author{
Zhanna Mingaleva* \\ Department of Economics and management in industrial production, Perm National Research Polytechnic University, Russia
}

Submission: November 21, 2017 ; Published: December 14, 2017

*Corresponding author: Zhanna Mingaleva, Department of Economics and management in industrial production, Perm National Research Polytechnic University (PNRPU), 29, Komsomolsky Av., Perm, Russian Federation, 614990, Russia, Email: mingal1@psu.ru

\begin{abstract}
Development and exploitation of oil fields is one of the leading factors in the transformation of the natural environment of the Perm region. The implementation of programs for monitoring the environmental safety of oil and gas fields is considered as the actual task of sustainable development of the territory and improvement of the life quality. The existence and development of oil fields in karstic areas located closely to the water reservoirs is one of the key features of the Perm region, posing high risks to the environment.
\end{abstract}

Keywords: Sustainable development; Pollution; Environment; Quality of life; Oil field

\section{Introduction}

TMore than 231 oil and gas fields are opened at the territory of Perm region, 174 have been developed, half of which have been operated for more than 30 years. Most of the multilayer deposits often have the so-called gas "cap". The structure of the types of hydrocarbon fields located in the Perm Region is shown in Figure 1. The structure of the total recoverable reserves of oil and gas by types and categories is shown in Table 1. Exploitation of many deposits leads to the natural and man-caused violation of the ecological balance.

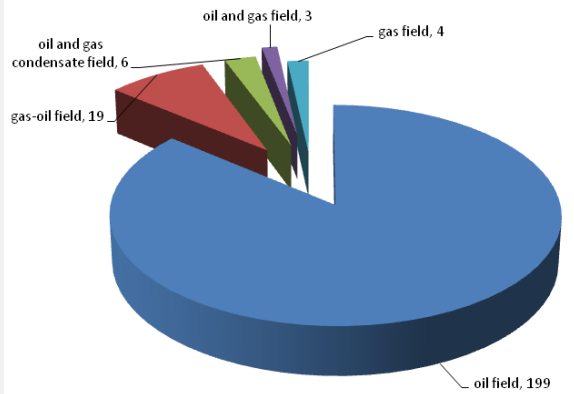

Figure 1: Structure of types of hydrocarbon deposits in the Perm Region.
Table 1: Structure of total recoverable hydrocarbon reserves by types and categories.

\begin{tabular}{|c|c|}
\hline Types of Hydrocarbon Deposits & $\begin{array}{c}\text { Total Recoverable } \\
\text { Reserves }\end{array}$ \\
\hline Oil of categories A+B+C1 & 514.94 million tons \\
\hline Oil of categories & 66.704 million tons \\
\hline $\begin{array}{c}\text { Free gas and gas of the gas cap of } \\
\text { categories B+C1 }\end{array}$ & 27.746 billion m3 \\
\hline $\begin{array}{c}\text { Free gas and gas of the gas cap of } \\
\text { categories C2 }\end{array}$ & 11.790 billion m3 \\
\hline $\begin{array}{c}\text { Associated gas (dissolved in oil of } \\
\text { categories A+B+C1) }\end{array}$ & 27.279 billion m3 \\
\hline $\begin{array}{c}\text { Associated gas (dissolved in oil of } \\
\text { categories C2) }\end{array}$ & 3.949 billion m3 \\
\hline
\end{tabular}

The Main Environmental Problems of the Use of Hydrocarbon Raw Materials

The main environmental problems associated with nonrenewable sources of energy and heats are usually reduced to the following ones. Firstly, the constant increase in the share of environmentally exploiting and polluting industries in the total output of most countries is an ever-increasing challenge of the world. It increases the environmental burden on the economy of separate countries, as well as on the global ecosystem as a whole. Existing technologies for processing traditional fuel and energy resources negatively affect the natural environment and 


\section{Recent Advances in Petrochemical Science}

the habitat of people. Waste of energy objects in the form of gas, liquid and solid phases causes negative changes in ecosystems at all levels: from local to global one. Heat-power engineering is a "producer" of huge masses of solid waste (coal, ash, slag's, etc.), which also violate the balance of existing ecosystems. As a result, production and society become an increasingly serious threat to the existence of life in general.

Secondly, there is an increase in environmental risks and risks of man-made disasters associated with the physical wear of equipment in oil and gas transportation systems and equipment for their processing. So 2 large enterprises of oil and gas industry are the main source of air pollution over the territory of Perm region. The largest contribution to the pollutant emissions from the total amount of emissions is made by hydrocarbon transportation enterprises (Gazprom transgaz Tchaikovsky LLC) 20.6\%; extraction of fuel and energy minerals (LUKOIL-Perm LLC) $-15.6 \%[1]$.

Thirdly, as a result of economic activity, people are aggravated by negative climate changes, global warming, as well as the growing negative impact of environmental pollution on human health are increasing. As it was noted in the study carried by the experts of International Energy Agency in 2016, the "the production and use of energy are certainly the largest anthropogenic sources of air pollutants" [2]. Especially the environmental consequences of the use of hydrocarbon raw materials are manifested in places where oil and gas are actively extracted and processed.

The Perm region is a territory with developed and intensive oil production. Traditionally, in assessing the transformation of natural and man-made areas, the state of individual natural components is assessed: the geological environment, atmospheric air, ground and surface water, soil cover, vegetation, and animal life $[3,4]$. Without considering all these components, we will briefly analyze the impact of the development of oil fields on atmospheric air and hydrogeology of the Perm region.

\section{Assessment of Pollution From Oil Fields of the Perm Region}

The development of hydrocarbon resources in the Perm Krai takes place under complex mining and geological (the conjunction of the Russian platform and the folded zone of the Urals) and specific hydrogeological conditions [5]. Territories with unprotected and poorly protected groundwater are in many cases karstic rocks territories [6].

Almost one third of the area of all oil fields in the Perm region is located in karstic areas. They occupy nearly $1300 \mathrm{~km}$. Petroleum deposits are mainly confined to Irene (30 deposits), Solikamskoye (29 deposits), Polaznensky and Ufa (each of 14 deposits), Nizhnesylvinsky Plateau (10 deposits), karst areas with the predominant development of gypsum and carbonate-gypsum karst, except Solikamsky salt karstic area [7].
The greatest danger to the environment from the point of view of the quality of people's life is represented by oil fields in the karstic areas located in the immediate vicinity of the reservoirs. In the Perm region, the total length of the coastline of the reservoirs is 3.5 thousand $\mathrm{km}, 25 \%$ of which passes through the territory of karstic areas. About $10 \%$ of the oil deposits associated with the karstic areas is located close to the water reservoirs [8].

Slopes of river valleys and reservoirs have the largest coefficient of karstic formation, rather than on the adjacent watershed, which leads to an increase in the vulnerability of the territory to pollution. So, for example, in the area of the village. Polazna (Kama reservoir) on the slope the coefficient of karstic formation is equal to 0.186 , and the number of funnels per square kilometer reaches 270 , and on the watershed these values are respectively equal to 0.036-0.004 and 17-30 [9]. At the watershed the runoff is local, which adapts to the most fractured zones. Approaching the reservoir, fissured-karstic waters form a single aquifer.

Measurements of the concentrations of pollutants in the air basin on the territory of oil fields in 2004-2013 were carried out to study atmospheric air quality [10]. The values obtained were compared with the background values and the normalized indices. Measurements of single concentrations of harmful substances in the ambient air under condition of accident-free work were carried out in the zone of influence of oilfield facilities (wells, group metering stations, booster pump stations, separating pumping plants, primary processing plants, etc.), as well as in settlements and selected background sites. To obtain objective information about the impact of the oil field on the air environment, the selection points were selected taking into account the prevailing wind direction [10].

As a result of a study of air pollution in major oil fields, it was found that in 2004-2013, the average values of the air pollution indices in the territory of Perm region deposits were practically unchanged. The level of concentrations of the chemical components studied was generally independent of such factors as the geographic location of the oil field, the duration of field operation and the number of sources of pollution (oil and gas producing wells). During the whole period of observation, single exceedances of air quality standards were recorded, indicating one-time emergency emissions. Based on the analysis of the presence of pollutants in the air to assess the transformation of natural-technogenic sections of oil fields, regular observations of the concentrations of aromatic hydrocarbons (benzene, toluene, xylene) and phenols are the most important [10].

\section{Conclusion}

Experience in the development of oil fields in the Perm Krai has shown that the problems of persistent, difficult to eliminate pollution of the environment are most acute in the areas of karst development. Karstic areas are marked by a significant decrease in the degree of protection of the underground hydrosphere. 
Deposits in protected and poorly protected areas should be given increased attention during operation. The main task of ensuring sustainable development of the territory and improving the quality of life of people is the implementation of programs to monitor the hydrological safety of oil and gas fields.

\section{Acknowledgement}

The work is carried out based on the task on fulfillment of government contractual work in the field of scientific activities as a part of base portion of the state task of the Ministry of Education and Science of the Russian Federation to Perm National Research Polytechnic University (the topic \#26.6884.2017/8.9 "Sustainable development of urban areas and the improvement of the human environment").

\section{References}

1. Federal Environmental Information of the Perm Region (2017) The federal service for supervision in the sphere of nature management.

2. (2016) World energy outlook special report 2016: energy and air pollution international energy agency. IEA Publications, Paris, France, p. 266.

3. Buzmakov SA (2005) Methods of geoecological research of oil-field transformation of terrestrial ecosystems. Geographical Bulletin 1-2: 138-148.

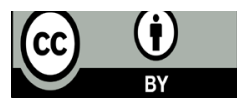

This work is licensed under Creative Commons Attribution 4.0 Licens
4. Bachurin BA, Odintsova TA, Borisov AA (2009) To the technique of identification of sources of oil pollution of the geological environment. Gorn Inform Analit Bul 8: 291-298.

5. Kostarev SM (2011) Actual problems in ecological hydrogeology during the development of oil-and-gas resources of Perm region. The electronic scientific journal Georesources, Geoenergetics, Geopolitics, $2(4)$.

6. Bykov VN (2002) Oil and gas karstology. Perm un-t Perm, Russia, p. 351.

7. Meshcheryakova OYu (2011) Peculiarities of oil pollution in the karst regions of the Perm Krai Geol Nauka in the developing world. Perm state un-t, Perm, Russia, pp. 254-256.

8. Maksimovich NG, Meshcheryakova OYu (2009) Methods of struggle against oil pollution on the karst banks of reservoirs. Ecology of urbanized territories 4: 55-58.

9. Maksimovich NG, Kazakevich SV, Nikiforov VV (2005) The role of karst in the formation of oil pollution of the hydrosphere in the area of the settlement of Polazna. Geology and minerals of the Western Urals, Perm University, Russia, pp. 290-295.

10. Chaykin SA (2014) Proceedings of the Samara Scientific Center of the Russian Academy of Sciences 16 (1/3): 692-694.

\section{Your next submission with Juniper Publishers will reach you the below assets}

- Quality Editorial service

- Swift Peer Review

- Reprints availability

- E-prints Service

- Manuscript Podcast for convenient understanding

- Global attainment for your research

- Manuscript accessibility in different formats

( Pdf, E-pub, Full Text, Audio)

- Unceasing customer service

Track the below URL for one-step submission https://juniperpublishers.com/online-submission.php 